Advances in Geosciences, 7, 205-213, 2006

SRef-ID: 1680-7359/adgeo/2006-7-205

European Geosciences Union

(c) 2006 Author(s). This work is licensed

under a Creative Commons License.

\title{
Rainfall events and Hailstorms Analysis Program (RHAP)
}

\author{
M. Ceperuelo ${ }^{1}$, M. C. Llasat $^{1}$, and T. Rigo ${ }^{2}$ \\ ${ }^{1}$ Department of Astronomy \& Meteorology, Faculty of Physics, University of Barcelona, Spain \\ ${ }^{2}$ Meteorological Service of Catalonia, Generalitat de Catalunya, Spain
}

Received: 7 October 2005 - Revised: 23 January 2006 - Accepted: 23 January 2006 - Published: 8 March 2006

\begin{abstract}
RHAP (Rainfall events and Hailstorms Analysis Program) is a new tool designed for analysing rainfall events and hailstorms. The aim of this contribution is to present the RHAP tool, which is under development, and its application to different hailstorms and rainfall episodes. The program assimilates multiple data bases (meteorological radar, meteorological model outputs, radiosondes and surface observations) with the purpose to get better event reanalysis. It is based on Storm Cell Identification and Tracking Algorithm (SCIT) with an improved version of the method, and also on a new 2-D algorithm which automatically identifies and classifies the precipitation systems distinguishing between Mesoscale Convective Systems, Multicellular systems, Isolated convection, Stratiform precipitation and Convective precipitation embedded in stratiform precipitation. These two methods allow to obtain the 2-D and 3-D features of the precipitation system like top height of the cells, maximum reflectivity, Vertical Integrated Liquid content (VIL) and VIL density (VILD), kinetic energy, severe hail probability (SHP), number of 3-D cells exceeding a given threshold, Z/R relations,... that are useful to analyse both heavy rainfall and hail events. As application, two events produced on NE Spain are discussed: the heavy rainfall event recorded on 6 September 2004 , characterised by a great number of cells that crossed the affected area and that had a maximum activity associated to high values of VIL $\left(37.5 \mathrm{~kg} / \mathrm{m}^{2}\right), Z_{\max }(54 \mathrm{dBZ})$ and SHP (73\%); and the hail event produced on 29 August 2004, with a rapid development of the convective system and with hail observations in surface when the following thresholds were exceeded: $Z_{\max }=54 \mathrm{dBZ}, \mathrm{VIL}=25 \mathrm{~kg} / \mathrm{m}^{2}$ and $\mathrm{SHP}=63 \%$.
\end{abstract}

\section{Introduction}

The northeast of Spain region (the Mediterranean coast and the Ebro Valley) is usually affected by heavy rainfall events

Correspondence to: M. Ceperuelo

(ceperuel@am.ub.es)
(Llasat and Rodriguez, 1992; Ramis et al., 1994; Llasat et al., 2003) and hailstorms (Font, 1983; López, 2003). Some works have been done in this region in order to characterise the heavy rainfall events (Rigo and Llasat, 2004) and hail events (Pascual, 2000; López, 2003), usually associated to well organized convective systems, and classifying them (Fraile et al., 2001; Sánchez et al., 2003; Rigo, 2004; Rigo and Llasat, 2004).

However, one of the problems to analyse heavy rainfall and hail events is how to integrate the multiple kinds of data: meteorological model, meteorological radar, radiosonde, satellite, lightning, surface observations,... To analyse or reanalyse these events it is necessary to take a look at all these information with the purpose to explain the reasons why it happened. This is usually done with different programs, methods and applications, e.g. programs developed to obtain radiosonde indexes (e.g. RAOB, RAwinsonde OBservation program), to analyse meteorological radar data (e.g. TITAN, Thunderstorm Identification, Tracking, Analysis and Nowcasting), etc.

Considering the problem of integrating different data and that the northeast of Spain is affected by hail and heavy rainfall events, a new tool for analysing these events is being developed and it is presented in this paper. The Rainfall events and Hailstorms Analysis Program (RHAP) has been created in order to improve the analysis, tracking and nowcasting of convective structures in hail and rainfall events by the assimilation of different kinds of data. Nowadays, RHAP integrates meteorological radar data, MM5 meteorological model outputs, radiosonde data and surface observations (hailpads and observers information). Moreover, RHAP gives the possibility to realize three different types of event analysis based on the precipitation structures identification by the meteorological radar, considering 2-D convective and stratiform regions (Steiner et al., 1995; Bigerstaff and Listemaa, 2000; Rigo, 2004), 3-D convective cells (Dixon and Wiener, 1993; Johnson et al., 1998; Rigo, 2004) and integrated precipitation systems (Fraile et al., 2001; Sánchez et al., 2003; Rigo and Llasat, 2004). 


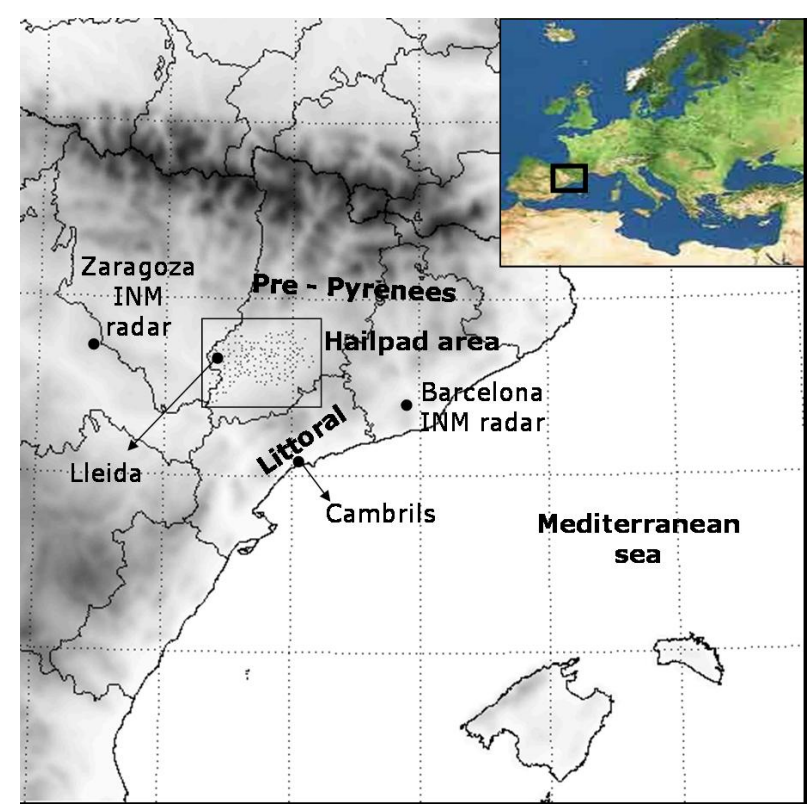

Fig. 1. Study area and locations.

In addition, RHAP can also be used for teaching new forecasters or as a forecaster tool to nowcast an event (future version of the program). Finally, the program code is written in Interactive Data Language in its version 6.0 (IDL 6.0) and can work under different operative systems.

Firstly the program is introduced. Next, the different kind of data and formats and the interface of the program are shown. Then, the most important algorithms, improved versions and the new algorithms used are explained. After that, two case studies produced in Catalonia are analysed: the hail event of 29 August 2004 recorded in the province of Lleida (Fig. 1), with hailstones larger than $25 \mathrm{~mm}$ in diameter and eighteen affected hailpads; and the heavy rain event of 6 September 2004 recorded in Cambrils (Fig. 1), with amounts of precipitation in three hours greater than $150 \mathrm{~mm}$. Finally, the conclusions have been explained.

\section{The data used and program interface}

The RHAP software has been designed to read and to integrate radar data, meteorological model outputs (wind field, ground temperature, accumulated rainfall, relative humidity...), radiosonde observations, ground observations and hailpads observations. This tool can operate using information provided by different meteorological radars, with different formats. All the information needed to add a new type of radar is the radar information: location, time and spatial resolution, number of CAPPIs and heights and type of projection.

In this work, radar data have been provided by the radars of Barcelona and Zaragoza, from the Instituto Nacional de Meteorología (INM), the radar of the University of Leon at
Table 1. MM5 parameterisations for the heavy rainfall and hail event.

\begin{tabular}{lccc}
\hline Parameterisation & D1 & D2 & D3 \\
\hline Moisture scheme & Reisner2 & Reisner2 & Reisner2 \\
Cumulus scheme & BM & KF & Non \\
PBL scheme & MRF & MRF & MRF \\
Radiation scheme & Cloud & Cloud & Cloud \\
Soil scheme & 5-Layer & 5-Layer & 5-Layer \\
Shallow convection & No & No & No \\
\hline
\end{tabular}

Zaragoza, and the three radars of the Meteorological Service of Catalonia (METEOCAT). Data format are McIdas, TITAN and IRIS, respectively.

On the other hand, the hail formation and heavy rain events usually are local events and they depend on the orography of the zone and on the environmental conditions which can trigger the convection that will produce the severe weather phenomena. It is to say that synoptic scale is not sufficient to study convective phenomenon and the use of a meteorological model is required to obtain mesoscale circulation (Llasat et al., 1997). In the RHAP case, the MM5 meteorological model has been used. MM5 allows reanalysing the event with different kind of parameterizations of convection and orography (Table 1). At the moment, data used in RHAP are MM5 meteorological model outputs with one hour of time resolution and eight kilometres of horizontal resolution. The files used are grid files for wind field at different levels (925, 850,700 and $500 \mathrm{hPa}$ ), ground temperature, relative humidity, accumulated rainfall, among others.

Otherwise, the vertical observation of the atmosphere is an important technique to obtain the instability of the atmosphere with instability indexes (Brooks and Craven, 2002 ${ }^{1}$; López, 2003). RHAP integrates these thermodynamic observations with radar data to obtain more parameters to identify a hail or a heavy rain event: VIL of the day (VOD), Kinetic Energy Flux, Waldvogel parameter, Hail probability (personalised relations), Severe Hail Probability (SHP), Maximum Expected Hail Size, Severe Hail Index and Warning Threshold. To do that, the program has an algorithm that realize the analysis of the radiosonde observation obtaining values of the instability indexes: total of totals (TTI), Showalter index (SI), K index (KI), SWEAT index, CAPE (Convective Available Potential Energy), wind shear, precipitable water, etc. Presently, the application works with two kinds of radiosonde formats: the University of Wyoming format and the METEOCAT format. Nevertheless it could work with any kind of radiosonde observation.

Furthermore, to study a hail or heavy rain event, surface observations as rainfall, hailpads or subjective observations

\footnotetext{
${ }^{1}$ Brooks, H. E. and Craven, J. P.: A database of proximity soundings for significant severe thunderstorms, 1957-1993, Preprints, 21 st Conference on Severe Local Storms, San Antonio, TX, Amer. Meteor. Soc., 639-642, 2002.
} 
are needed (Schleusener and Jenings, 1960; López, 2003). For this reason they have also been integrated in RHAP. The hailpad network used along this paper belongs to the "Associació de Defensa dels Vegetals" of Lleida (Fig. 1), which is composed by 170 hailpads. The network density is close to 1 hailpad per $16 \mathrm{~km}^{2}$ and gives, among others, values of maximum hail size, ice mass, kinetic energy and number of impacts per $\mathrm{m}^{2}$.

Finally, the interface of the program (Fig. 2) is based on a menu with interactive applications and buttons which make RHAP dynamics. It also offers the availability of multiple representations using the different applications. The product is composed by the representation area, $\mathrm{X}$ and $\mathrm{Y}$ projections of the maximum reflectivity, legend information and tables with obtained values of different interactive options: general features of the radar data, features of the selected 2-D structure, 3-D cell or precipitation system and radiosonde parameters.

\section{Parameters and algorithms}

The objective of RHAP is to analyse rainfall and hail events. That is the reason why the program has included a great number of radar parameters to identify severe weather: Maximum reflectivity, Z/R relation (Marshall and Palmer, 1948), Beta parameter (Llasat et al., 2005), VIL "Vertical Integrated Liquid" (Greene and Clark, 1972), VILD "VIL density" (Amburn and Wolf, 1997), VOD "VIL of the Day" (San Ambrosio, 2005; Paxton and Shepherd, 1993), H45 "Waldvogel Parameter" and HP "Hail Probability" (Waldvogel et al., 1979; Holleman, 2001), SHP "Severe Hail Probability" (Witt et al., 1998), MEHS "Maximum Expected Hail Size" (Witt et al., 1998), kinetic energy (Waldvogel et al., 1978; and Witt et al., 1998) and ECHOTOPS of 20, 30 and $40 \mathrm{dBZ}$. All these parameters are obtained and are included in the 3-D cells and precipitation systems characterisation.

The most important algorithms of RHAP have been divided in three different methods: 2-D structures, 3-D cells and Precipitation Systems.

\subsection{2-D structures}

The algorithms are based on Steiner et al. (1995), Bigerstaff and Listemaa (2000) and Rigo and Llasat (2004) and the objective of them is to identify areas with convective or stratiform precipitation. Firstly, the identification algorithm searches for those zones over a threshold reflectivity $(43 \mathrm{dBz})$ and they are assigned as convective pixels. Then, it searches for those pixels that satisfy a gradient criteria and the algorithm assign them as convective. After that, it searches for pixels in smaller radius than $r_{c}$, where $r_{c}$ is a threshold radio which depends on the reflectivity value of the considered pixel (see Steiner et al., 1995 for more details). Next, the algorithm applies a correction for convective and stratiform pixels based on the bright band. Finally, it searches for those regions with an area over a threshold value.

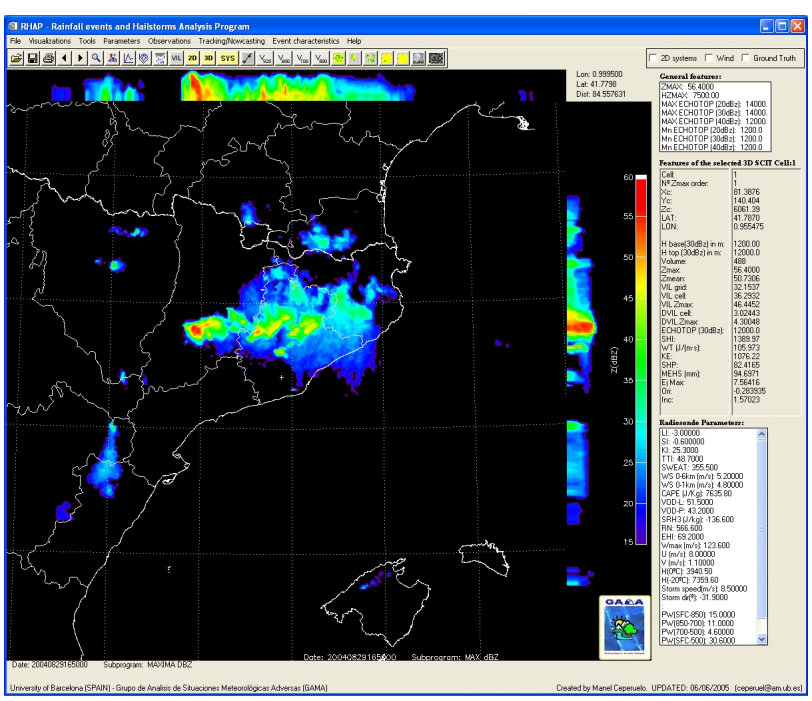

Fig. 2. RHAP interface.

In the case of the 2-D structures tracking method, the correlation method (Collier, 1989; Circe and Martín, 2003; Rigo, 2004) which searches for similar and nearly structures in the previous time has been used.

\subsection{3 -D cells}

The 3-D cells identification algorithm is based on the SCITStorm Cell Identification and Tracking method (Johnson et al., 1998) and on the work of Rigo (2004). It works in volume mode. Firstly, it searches for 2-D cells in each level that satisfy the threshold reflectivity condition $(30,35,40,45,50$, 55 and $60 \mathrm{dBz}$ ) and covers an area greater than the area condition $\left(24 \mathrm{~km}^{2}\right)$. Then, the 2-D cells of each level are connected with a distance condition requisite $(8 \mathrm{~km})$. The features of the identified 3-D cells are: volume, index, centroid position ( $\mathrm{x}, \mathrm{y}, \mathrm{z}$, latitude and longitude), maximum reflectivity, mean reflectivity, top high, base high, VIL (grid, cellular and $Z_{\max }$ ), VILD (grid, zmax), kinetic energy, severe hail probability, maximum expected hail size, tilt, maximum axis and orientation.

The tracking algorithm of 3-D cells is a combination of Dixon and Wiener (1993) and a RHAP algorithm. Firstly, the algorithm identifies the 3-D cells and their features. Then, an extrapolation to the previous time position is done using the radar time resolution and the mean grid wind, which is obtained as a medium value of the $925,850,700$ and $500 \mathrm{hPa}$ meteorological model winds. After obtaining the first previous position, the method searches in previous real radar data for the 3-D cell that satisfies the TITAN condition (for more details see Dixon and Wiener, 1993). All 3-D cells are tracked using this criterion.

Finally, when a 3-D cell has been tracked, it is possible that it could be the time evolution of different cells. It is to say that the first cell detected could develop one more cell in its dissipating phase but the tracking algorithm considers this 
Table 2. Automatic classification of precipitation systems.

\begin{tabular}{llll}
\hline Precipitation System & Horizontal Dimension & Convective percentage & Duration \\
\hline MCS & $\mathrm{d}>100 \mathrm{~km}$ & Convective area $(\mathrm{CA})>30 \%$ & $\mathrm{t}>3 \mathrm{~h}$ \\
MUL & $50 \mathrm{~km}<\mathrm{d}<200 \mathrm{~km}$ & $\mathrm{CA}>30 \%$ & - \\
ISO & $\mathrm{d}<50 \mathrm{~km}$ & $\mathrm{CA}>30 \%$ & - \\
EST-EMB & $\mathrm{d}>0 \mathrm{~km}$ & $5 \%<\mathrm{CA}<30 \%$ & - \\
EST & $\mathrm{d}>0 \mathrm{~km}$ & $\mathrm{CA}<5 \%$ & - \\
\hline
\end{tabular}

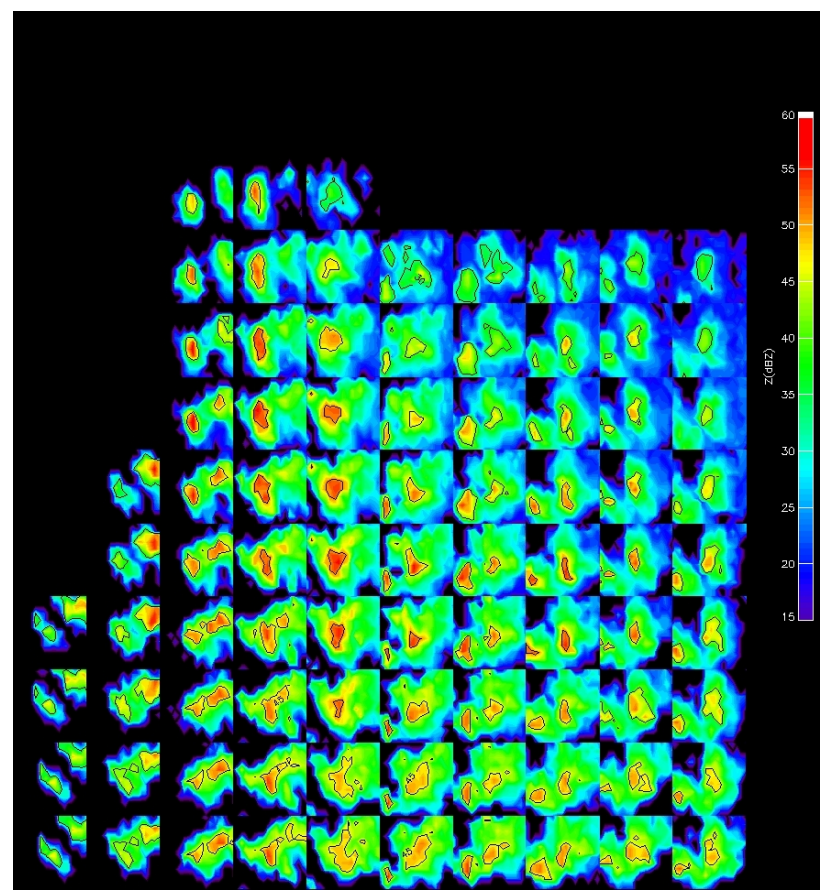

Fig. 3. 2-D contour (black line) at each level of the tracked northern 3-D hail cell of 29 August 2004 between 16:20 and 17:50 UTC.

newer cell as the same cell that the previous one. To solve this problem a tracking reanalysis based on VIL parameter evolution has been proposed. The method is based on the vertical distribution of the 3-D cell reflectivities (Fig. 3). After obtaining the tracked 3-D cell, the algorithm searches those zones of the cell life cycle where VIL parameter has strong fluctuations. This only occurs when the vertical distribution of reflectivities has been changed. It implies that different cells have been detected.

\subsection{Precipitation systems}

The Precipitation systems identification is based on 2-D structures identification after applying the 2-D algorithms described before. An automatic classification of all the precipitation system identified is being done with a new algorithm developed and taking into account the Rigo and Llasat (2004) classification, which is based on the area, percentage covered by the convective precipitation and duration of the sys- tem. By this way, the systems can be classified as mesoscale convective systems (MCS), multicellular system (MUL), isolated convection (ISO), convective precipitation embedded in stratiform precipitation (EST-EMB) and stratiform precipitation (EST). The automatic classification proposed is shown in Table 2, the program searches for 2-D regions and then it classifies each region as a system. Moreover, RHAP allows characterising the precipitation systems, obtaining the present features: type of system, area, percentage of convective precipitation area, centroid position, maximum axis, number and identifier of 3-D cells and number and identifiers of 3-D cells with reflectivity greater than $50 \mathrm{dBZ}$, maximum reflectivity, mean reflectivity of 3-D cells maximum reflectivity, echotop mean value, mean value of 3-D cells bases, maximum VIL value and maximum VILD value of 3-D cells.

The tracking method of the precipitation systems is based on the correlation method which searches for similar regions in the previous image, as the 2-D structures case. An example of the precipitation system tracking is shown in Fig. 4 where some precipitation system variables have been drawn.

\section{Case studies}

Two different case studies have been analysed in order to test the program: the hail event of 29 August 2004, which affected the hailpad covered area of Lleida and produced hailstones with $25.41 \mathrm{~mm}$ diameter, and the heavy rain event of 6 September 2004, which affected the town of Cambrils producing three deaths and recorded a maximum accumulated rainfall of $158.2 \mathrm{~mm}$.

The general circulation and mesoscale reanalysis of the events have shown that:

1. The hail event was a typical storm-forming situation with a thermal low over the Iberian Peninsula and a cold front that crossed the north of Spain. The mesoscale reanalysis showed south-western wind flow and maximum surface temperatures over hailpad area. The moisture advection to the zone, the wind blowing towards the Pre-Pyrenees mountainous system and the moment after the maximum of solar irradiance triggered the convection (Fig. 5).

2. The heavy rain event was characterised by the presence of a deep low centred over the Iberian Peninsula and an important presence of a cold air at upper 
Radar parameter evolution of the precipitation system of the Cambrils heavy rain event (06/09/2004)

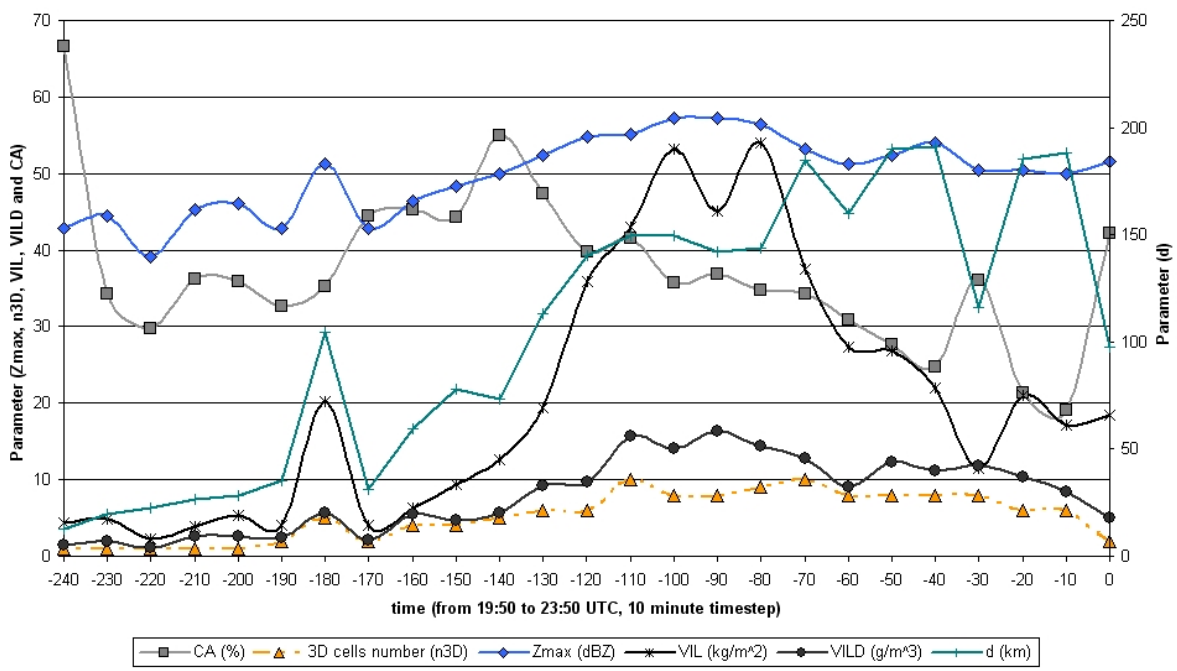

Fig. 4. Radar parameters evolution of the precipitation system of the 6 September 2004 Cambrils heavy rain event: Convective precipitation area percentage $(\mathrm{CA})$, number of 3-D cells belonging to the precipitation system (n3-D), maximum reflectivity $\left(\mathrm{Z}_{\max }\right)$, vertical integrated liquid (VIL), vertical integrated liquid density (VILD) and maximum horizontal dimension (d).

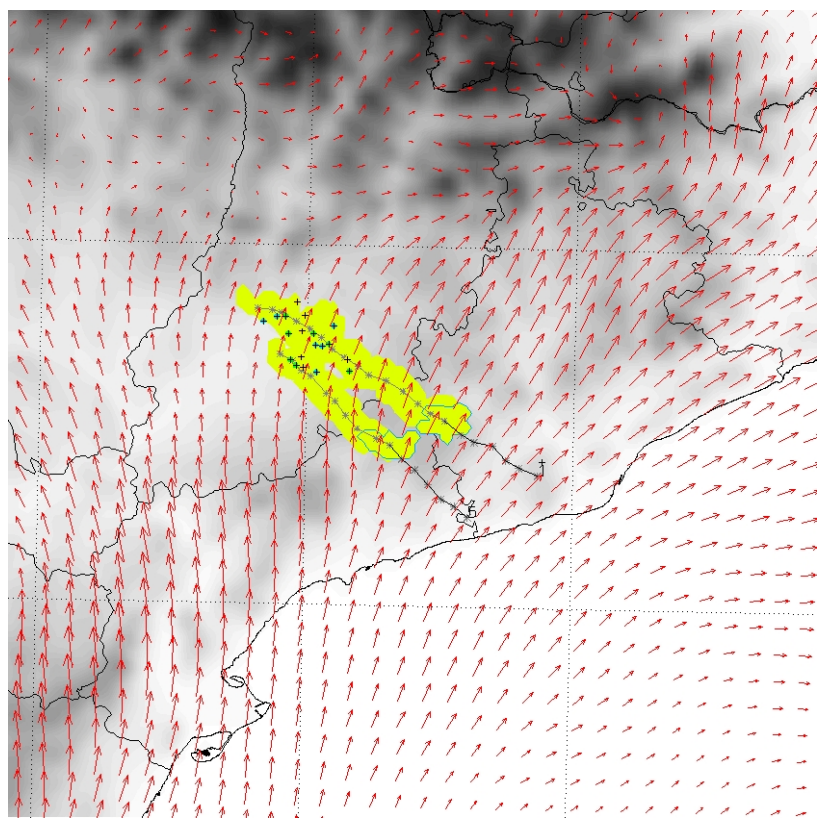

Fig. 5. Trajectory (grey line) and area covered (yellow) from 16:20 to $18: 40$ UTC for the northern cell and from $17: 10$ to $18: 40$ UTC for the southern cell. 60 min nowcasting (black) of the 3-D cells. Ground hail observations and $925 \mathrm{hPa}$ wind are also shown.

levels. The mesoscale reanalysis showed an eastern and south-eastern wind flow that blew towards the Prelittoral mountainous system providing moisture advection over the affected area of Cambrils and high temperatures near the Mediterranean Sea (Fig. 6).

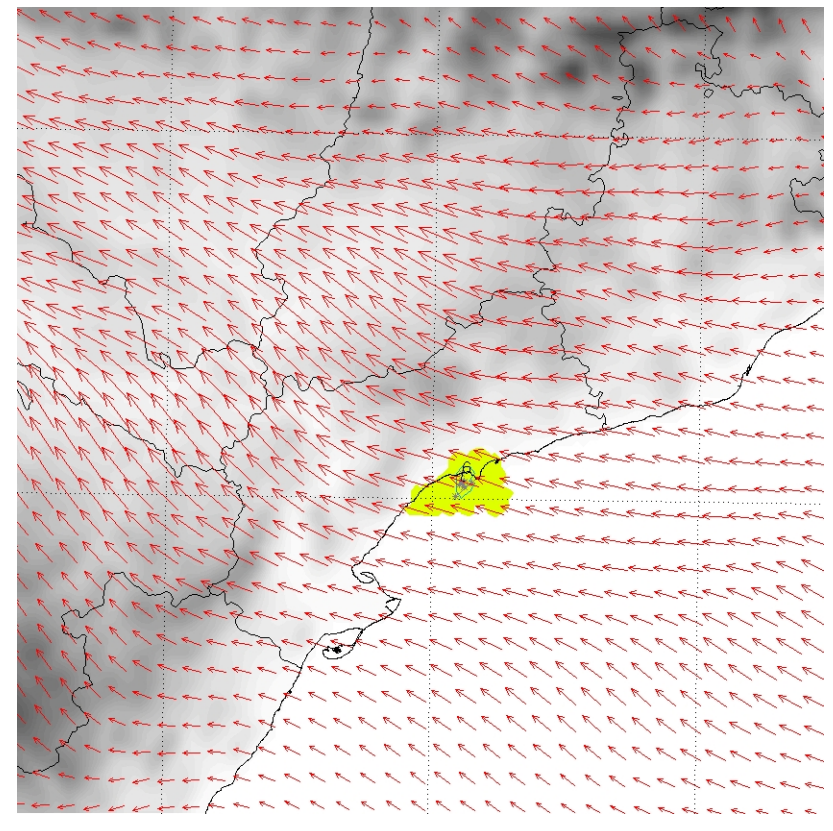

Fig. 6. Trajectory, area covered (22:30-23:20 UTC) and nowcast $(60 \mathrm{~min})$ of one of the heaviest cells of the heavy rainfall event. $925 \mathrm{hPa}$ wind is also shown.

From a thermodynamic point of view, both events were characterised by the instability indexes (Table 3 ) obtained for the Lleida radiosonde. The hail event was characterised with instability indexes as high as CAPE $=7635.8 \mathrm{~J} / \mathrm{kg}$ and TTI $=48.7$, and high values of precipitable water mass in low levels $\left(15 \mathrm{~kg} / \mathrm{m}^{2}\right.$ in $\mathrm{SFC}-850 \mathrm{hPa}$ layer $)$. In the heavy rain case, the CAPE value was very low $(65.0 \mathrm{~J} / \mathrm{kg})$ and the precipitable water content in low levels $\left(11.8 \mathrm{~kg} / \mathrm{m}^{2}\right)$ was lower, 
Table 3. Lleida Radiosonde parameters for hail event and heavy rain event.

\begin{tabular}{lcc}
\hline & Hail event & Heavy Rain event \\
& $(29 / 08 / 2004-12: 00$ UTC $)$ & $\begin{array}{c}\text { Value } \\
(06 / 09 / 2004-12: 00 \text { UTC })\end{array}$ \\
\hline Radiosonde Parameter & -3.0 & Value \\
\hline Lifted Index & -0.6 & -3.2 \\
Showalter Index & 25.3 & -1.7 \\
K Index & 48.7 & 23.3 \\
Total of Totals Index & 355.5 & 51.8 \\
SWEAT index & 5.2 & 285.3 \\
Wind Shear 0-6 km (m/s) & 4.8 & 7.0 \\
Wind Shear 0-1 km (m/s) & 7635.8 & 7.4 \\
CAPE (J/kg) & 51.5 & 65.0 \\
VIL of the Day: VOD “Lewis III" $\left(\mathrm{kg} / \mathrm{m}^{2}\right)$ & 43.2 & 48.8 \\
VOD “Paxton and Shepherd" $\left(\mathrm{kg} / \mathrm{m}^{2}\right)$ & 123.6 & 40.1 \\
Wmax (m/s) & 3940.5 & 11.4 \\
$0^{\circ}$ C height (m) & 7359.6 & 4140.9 \\
-20 C height $(\mathrm{m})$ & 15.0 & 6952.9 \\
Precipitable water: SFC-850 $\left(\mathrm{kg} / \mathrm{m}^{2}\right)$ & 11.0 & 11.8 \\
Precipitable water: 850-700 $\left(\mathrm{kg} / \mathrm{m}^{2}\right)$ & 4.6 & 9.0 \\
Precipitable water: $700-500\left(\mathrm{~kg} / \mathrm{m}^{2}\right)$ & 31.0 & 3.5 \\
Precipitable water: SFC-300 $\left(\mathrm{kg} / \mathrm{m}^{2}\right)$ & & 24.8 \\
\hline
\end{tabular}

Table 4. Life time evolution of some radar parameters of the northern 3-D hail cell of the hail event from 18:40 UTC to 16:20 UTC: Maximum reflectivity $\left(\mathrm{Z}_{\max }\right)$, Vertical Integrated Liquid (VIL), VIL density (VILD), Kinetic energy (KE), Severe hail probability (SHP) and Maximum expected hail size (MEHS).

\begin{tabular}{cccccccc}
\hline Time $(\mathrm{UTC})$ & Hail & $\mathrm{Z}_{\max }(\mathrm{dBZ})$ & $\mathrm{VIL}\left(\mathrm{kg} / \mathrm{m}^{2}\right)$ & $\mathrm{VILD}\left(\mathrm{g} / \mathrm{m}^{3}\right)$ & $\mathrm{KE}\left(\mathrm{J} / \mathrm{m}^{2}\right)$ & MEHS $(\mathrm{mm})$ & SHP $(\%)$ \\
\hline $18: 40$ & No data & 47.2 & 7.8 & 1.2 & 60.2 & 7.43 & 18.3 \\
$18: 30$ & No data & 50.0 & 14.6 & 1.7 & 193.6 & 21.10 & 44.6 \\
$18: 20$ & No data & 52.0 & 16.7 & 1.5 & 224.5 & 22.46 & 46.2 \\
$18: 10$ & No data & 48.4 & 11.3 & 1.5 & 130.4 & 14.80 & 35.7 \\
$18: 00$ & No data & 51.2 & 11.8 & 1.3 & 140.2 & 11.61 & 29.6 \\
$17: 50$ & No data & 50.8 & 15.5 & 1.8 & 233.7 & 23.63 & 47.5 \\
$17: 40$ & No & 54.0 & 26.0 & 3.0 & 547.1 & 49.41 & 66.0 \\
$17: 30$ & Yes & 56.8 & 32.8 & 3.7 & 777.0 & 60.68 & 71.2 \\
$17: 20$ & No & 53.2 & 24.1 & 2.7 & 484.7 & 46.39 & 64.4 \\
$17: 10$ & Yes & 56.0 & 26.1 & 3.0 & 562.3 & 46.57 & 64.5 \\
$17: 00$ & Yes & 57.2 & 34.8 & 3.2 & 762.8 & 63.70 & 72.4 \\
$16: 50$ & Yes & 56.4 & 46.4 & 4.3 & 1076.2 & 94.70 & 82.4 \\
$16: 40$ & Yes & 59.2 & 46.6 & 4.3 & 1099.1 & 102.37 & 84.4 \\
$16: 30$ & No & 48.4 & 8.0 & 1.5 & 84.1 & 9.72 & 25.1 \\
$16: 20$ & No & 47.6 & 5.3 & 1.6 & 62.5 & 2.96 & 0.0 \\
\hline
\end{tabular}

but there were no valid for the Cambrils case due to the radiosounding of Lleida is far from the Mediterranean Sea influence on this event.

Using radar data, we have been focused on those precipitation systems and 3-D cells that produced hail (in hailpad covered area for the case of 29 August 2004) and those that produced heavy rains (Cambrils cells on 6 September 2004).

1. In the 29 August 2004 case, the hail observations were produced by two different cells, the northern one (Ta- ble 4) and southern one (Table 5), which moved parallel from northwest to southeast (Fig. 5) following the mean wind direction obtained by the MM5 meteorological model. The associated precipitation system that produced hail in the northern cell begun as an EMB-EST system at 16:10 UTC. Then it developed into an ISO system at 16:20 UTC and at 16:30 UTC it merged with a MUL system, moment where hail in surface was observed. At 17:00 UTC, the system that produced hail in 
Table 5. Life time evolution of some radar parameters of the southern 3-D hail cell of the hail event from 18:40 UTC to 17:10 UTC: Maximum reflectivity $\left(\mathrm{Z}_{\max }\right)$, Vertical Integrated Liquid (VIL), VIL density (VILD), Kinetic energy (KE), Severe hail probability (SHP) and Maximum expected hail size (MEHS).

\begin{tabular}{cccccccc}
\hline Time $(\mathrm{UTC})$ & Hail & $\mathrm{Z}_{\max }(\mathrm{dBZ})$ & $\mathrm{VIL}\left(\mathrm{kg} / \mathrm{m}^{2}\right)$ & $\mathrm{VILD}\left(\mathrm{g} / \mathrm{m}^{3}\right)$ & $\mathrm{KE}\left(\mathrm{J} / \mathrm{m}^{2}\right)$ & MEHS $(\mathrm{mm})$ & SHP $(\%)$ \\
\hline $18: 40$ & No data & 45.6 & 2.8 & 1.2 & 21.8 & 0.00 & 0.0 \\
$18: 30$ & No data & 51.6 & 7.9 & 1.8 & 138.8 & 2.15 & 0.0 \\
$18: 20$ & No data & 58.8 & 23 & 2.6 & 558.0 & 23.77 & 47.6 \\
$18: 10$ & No data & 58.8 & 37.8 & 4.3 & 998.1 & 64.53 & 72.8 \\
$18: 00$ & No data & 55.2 & 19.8 & 2.7 & 399.6 & 37.85 & 59.3 \\
$17: 50$ & No data & 54.0 & 18.9 & 3.0 & 416.2 & 23.80 & 47.6 \\
$17: 40$ & No & 50.4 & 17.1 & 1.9 & 273.0 & 29.55 & 53.1 \\
$17: 30$ & Yes & 54.0 & 25.1 & 2.8 & 532.2 & 44.75 & 63.5 \\
$17: 20$ & Yes & 55.6 & 31.8 & 3.6 & 772.9 & 53.2 & 67.9 \\
$17: 10$ & Yes & 56.8 & 34.4 & 3.9 & 870.6 & 49.37 & 66.0 \\
\hline
\end{tabular}

Table 6. Life time evolution of some radar parameters of the heaviest 3-D cell of the Heavy rain event. From 22:30 UTC to 23:20 UTC: Maximum reflectivity $\left(\mathrm{Z}_{\max }\right)$, Vertical Integrated Liquid (VIL), VIL density (VILD), Kinetic energy (KE), Severe hail probability (SHP) and Maximum expected hail size (MEHS).

\begin{tabular}{ccccccc}
\hline Time $(\mathrm{UTC})$ & $\mathrm{Z}_{\max }(\mathrm{dBZ})$ & $\mathrm{VIL}\left(\mathrm{kg} / \mathrm{m}^{2}\right)$ & $\mathrm{VILD}\left(\mathrm{g} / \mathrm{m}^{3}\right)$ & $\mathrm{KE}\left(\mathrm{J} / \mathrm{m}^{2}\right)$ & MEHS $(\mathrm{mm})$ & $\mathrm{SHP}(\%)$ \\
\hline $23: 20$ & 50.4 & 5.2 & 2.6 & 154.1 & 0.00 & 0.0 \\
$23: 10$ & 54 & 22 & 2.1 & 407.4 & 28.29 & 50.7 \\
$23: 00$ & 52.4 & 26.8 & 2.1 & 491.6 & 45.72 & 62.8 \\
$22: 50$ & 51.2 & 27.3 & 2.2 & 451.5 & 50.64 & 65.3 \\
$22: 40$ & 53.2 & 37.5 & 3.0 & 747.0 & 68.75 & 73.0 \\
$22: 30$ & 41.6 & 1.0 & 0.7 & 1.5 & 4.92 & 6.6 \\
\hline
\end{tabular}

the southern cell begun to develop and it was classified as an ISO system. At 17:10 UTC, it merged with the MUL system of the northern cell, and hail observations were produced. The MUL system lasted till 17:50 UTC, when it evolved as an ISO system. At 18:30 UTC, the system changed to a MUL system but it rapidly disappeared. Summarising the precipitation systems analysis, the hail observations in both cases were produced by a MUL system which lasted between 50 and $80 \mathrm{~min}$.

Analysing the 3-D convective cells, the hail observations in hailpad area were produced from the beginning of the storm formation due to the rapid development induced by the high atmospheric instability. The hailpad observations were produced with values of $Z_{\max }>54 \mathrm{dBZ}, \mathrm{VIL}>25 \mathrm{~kg} / \mathrm{m}^{2}, \mathrm{HP}>92 \%$ and SHP $>63 \%$. In no hailpad covered area there were moments where all this conditions were fulfilled; probably they observed hail phenomenon but there were no surface observations.

2. In the heavy rain event of Cambrils, the amount of precipitation was produced by different cells that moved from the Mediterranean Sea to the coast from 20:00 UTC to 23:50 UTC. These cells had a south to north movement which was blocked by the Littoral mountainous system. The cells were characterised by a short life cycle (30-60 min) and not very high values of reflectivity $(40-54 \mathrm{dBz})$. Figure 6 shows the area covered by one of the heaviest cell that contributed to the event. That cell (Table 6) was characterised by maximum $Z_{\max }$ value of $54 \mathrm{dBZ}$, VIL value of $37.5 \mathrm{~kg} / \mathrm{m}^{2}$ and SHP value of $73 \%$. On the other hand, the precipitation system that produced heavy rain (Fig. 4) begun as an ISO system at 19:50 UTC and it lasted till 21:00 UTC. At 21:10 UTC, it evolved to a MUL system which affected the Cambrils area till 2250UTC. At 23:00 UTC, the precipitation system changed to an EMB-EST system. Then it experienced some changes of size and convective precipitation which induced modifications in the type of system classification (EMB-EST to MUL and MUL to EMB-EST). At 23:50 UTC the MUL system begun to move in south-west direction far from Cambrils zone.

\section{Conclusions}

In this contribution the Rainfall events and Hailstorms Analysis Program has been presented. RHAP has improved the meteorological event analysis merging multiple kinds of 
data: meteorological radar data, meteorological model outputs, radiosonde observations and ground observations. It has been designed to analyse heavy rainfall and hail events, nevertheless, it can be used to study any kind of severe weather event. The most important applications of RHAP are the identification, characterisation and tracking of an event and the possibility to improve the nowcasting of radar parameters. The main tool of RHAP is the convective structures analysis, where different kind of studies can be carried out: 2-D structures, 3-D convective cells and precipitation systems. This last one has been shown as a new automatic method for analysing the event.

To test the program, two different case studies have been analysed: the heavy rainfall event of 6 September 2004 and the hailstorm event of 29 August 2004. The analysis of the respective convective cells and precipitation systems has allowed obtaining different features:

- The heavy rain event has been a stationary case with a great number of cells crossing the affected area during $3 \mathrm{~h}$. On the other hand, the hail event has had a northwest-southeast $100 \mathrm{~km}$ displacement.

- In the case of hail event, the cells have had a rapid development with a long life cycle. Nevertheless, the heavy rain event has had a short life cycle of 3-D cells.

- The hail systems have been characterised by the fast development of the convective system, forming multicellular systems with fast increasing of reflectivity values. The heavy rain event has been characterised with the slow development of the cells which have been intensified close to the coast.

- In the heavy rain case, some hail observations could be obtained comparing values of the 3D convective cells characterisation. High values of VIL, $Z_{\max }, \mathrm{HP}$ and SHP have been observed $\left(\mathrm{VIL}=37.5 \mathrm{~kg} / \mathrm{m}^{2}, Z_{\max }=54 \mathrm{dBZ}, \mathrm{SHP}=73 \%\right.$ and $\mathrm{HP}=100 \%$ ) which are greater than the ones obtained from the hail event: $Z_{\max }>54 \mathrm{dBZ}, V I L>25 \mathrm{~kg} / \mathrm{m}^{2}$, $\mathrm{HP}>92 \%$ and $\mathrm{SHP}>63 \%$.

To conclude, RHAP has been shown as a new tool to improve the events reanalysis. The easy way to obtain features and identification of 3-D cells and precipitation systems has allowed differentiating between the hail and heavy rain cases. Moreover, the tracking analysis has made possible to identify the long-lived 3-D cells of the hail event and the short-lived 3 -D cells of the heavy rain event.

Acknowledgements. The authors thank the MONEGRO (REN2003-09617-C02-02) Spanish project and to AMPHORE Interreg IIIB project, for enabling the drawing up and presentation of this contribution. Our thanks to the Associació de Defensa dels Vegetals, Maite Torà and Marta Masot, to the Meteorological Service of Catalonia of the Generalitat de Catalunya and to the Instituto Nacional de Meteorología for the hailpad data, radiosonde data and radar data and, finally, thanks to the University of León and the observers of Aragón for ground truth data.
Edited by: V. Kotroni and K. Lagouvardos

Reviewed by: T. Karacostas

\section{References}

Amburn, S. and Wolf, P.: VIL Density as a Hail indicator, Weather and Forecasting, 12, 473-478, 1997.

Biggerstaff, M. I. and Listemaa, S. A.: An Improved Scheme for Convective/Stratiform Echo Classification Using Radar Reflectivity, J. Appl. Meteorol., 39, 12, 2129-2150, 2000.

Circe, M. and Martin, F.: Automatic identification and tracking of convective structures from meteorological radars (In Spanish: Identificación y seguimiento automático de estructuras convectivas a partir de datos de radares meteorológicos), Nota técnica, STAP No. 39, 2003.

Collier, C. G.: Applications of Weather Radar Systems, Ellis Horwood, London, 1989.

Dixon, M. and Wiener, G.: Thunderstorm Identification, Tracking, Analysis and Nowcasting - A Radar-based Methodology, J. Atmos. Oceanic Technol., 10, 6, 785-797, 1993.

Font, I.: Climatological Atlas of Spain (in Spanish: Atlas Climático de España), INM and Ministerio de Transportes, Turismo y Comunicaciones, Madrid, 296, 1983.

Fraile, R., Castro, A., Sánchez, J. L., Marcos, J. L., and López, L.: Noteworthy C-band radar parameters of storms on hail days in north-western Spain, Atmos. Res., 59-60, 41-61, 2001.

Greene, D. R. and Clark, R. A.: Vertically Integrated Liquid: a new analysis tool, Mon. Wea. Rev., 100, 548-552, 1972.

Holleman, I.: Hail detection using single-polarization radar, Scientific report WR-2001-01, Royal Netherlands Meteorological Institute (KNMI), 2001.

Johnson, J. Y., MacKeen, P. L., Witt, A., Mitchell, E. D., Stumpf, G. J., Eilts, M. D., and Thomas, K. W.: The Storm Cell Identification and Tracking (SCIT) Algorithm: An Enhanced WSR-88D Algorithm, Weather and Forecasting, 13, 263-276, 1998.

Llasat, M. C., Gibergans, J., Guilbaud, S., and Rodríguez, J. Y.: The use of the vertical thermodynamic data in the daily classification: application to the improvement of an analog technique, INM/WMO International Symposium on Cyclones and Hazardous Weather in the Mediterranean, Palma de Mallorca, 395-402, 1997.

Llasat, M. C. and Rodriguez, R.: Extreme rainfall events in Catalonia: the case of 12 November 1988, Nat. Hazards, 5, 133-151, 1992.

Llasat, M. C., Rigo, T., and Barriendos, M.: The "Montserrat-2000" flash-flood event: a comparison with the floods in the Northeastern Iberian Peninsula since the 14th century, Int. J. Climatol., 23, 453-469, 2003.

Llasat, M. C., Rigo, T., Ceperuelo, M. ,and Barrera, A.: Estimation of the convective precipitation: the meteorological radar versus an automatic raingauge network, Adv. Geosci., 2, 103-109, 2005.

López, L.: Atmospheric severe convection: forecasting and identificating hailstorms (in Spanish), Doctoral Thesis, University of León, 2003.

Marshall, J. S. and Palmer, W. M. K.: The distribution of raindrops with size, J. Meteor., 5, 156-166, 1948.

Pascual, R.: Study of hailstorms in the Lleida region (in Spanish). Technical note no 3, Regional Meteorological Centre of Catalonia, 2000. 
Paxton, C. H. and Shepherd, J. M.: Radar Diagnostic Parameters as Indicators of Severe Weather in Central Florida, NOAA Tech. Memo. NWS SR-149, 12, 1993.

Ramis, C., Llasat, M. C., Genovés, A., and Jansà, A.: The October1987 floods in Catalonia: synoptic and mesoscale mechanisms, Meteorol. Applicat., 1, 337-350, 1994.

Rigo, T.: Study of Occidental Mediterranean Convective Mesoscale Systems using meteorological radar (in Spanish), Doctoral Thesis, University of Barcelona, Internal publication, 2004.

Rigo, T. and Llasat, M. C.: A methodology of convective structures using meteorological radar: application to heavy rainfall events on the Mediterranean coast of the Iberian Peninsula, Nat. Hazards Earth Syst. Sci., 4, 59-68, 2004.

Sánchez, J. L., Fernández, M. V., Fernández, J. T., Tudurí, E., and Ramis, C.: Analysis of mesoscale convective systems with hail precipitation, Atmos. Res., 67-68, 573-588, 2003.
San Ambrosio, I.: Radar-based module for hail estimation (in Spanish), STAP Technical Note no. 44, 2005.

Schleusener, R. A. and Jenings, P. C.: An energy method for relative estimates of hail intensity, Bull. Amer. Meteor. Soc., 41, 372376, 1960.

Steiner, M., Houze Jr., R. A., and Yutter, S. E.: Climatological Characterization of Three-Dimensional Storm Structure from Operational Radar and Rain Gage Data, J. Appl. Meteor., 34(9), 19782007, 1995.

Waldvogel, A., Federer, B., Schmid, W., and Mezeix, J. F.: The kinetic energy of hailfalls, Part II. Radar and hailpads, J. Appl. Meteorol., 17, 1680-1693, 1978.

Waldvogel, A., Federer, B., and Grimm, P.: Criteria for the detection of hail, J. Appl. Meteorol., 16, 1521-1525, 1979.

Witt, A., Eilts, M. D., Stumpf, G. J., Johnson, J. T., Mitchell, E. D., and Thomas, K. W.: An enhanced hail detection algorithm for the WSR-88D, Weather and Forecasting, 13, 286-303, 1998. 